\title{
RUMOURS IN A SITUATION OF POLITICAL CONFLICT: CATALONIA AND ITS REFERENDUM OF SELF-DETERMINATION
}

\author{
Emili Samper \\ Department of Catalan Studies \\ Rovira i Virgili University, Tarragona, Spain \\ emili.samper@urv.cat \\ Carme Oriol \\ Department of Catalan Studies \\ Rovira i Virgili University, Tarragona, Spain \\ carme.oriol@urv.cat
}

\begin{abstract}
Catalonia is in a situation of political conflict with the Spanish State regarding its right to self-determination, a conflict that has been exacerbated in recent years by the growing demand from a part of Catalan society for an independent state. Throughout this situation rumours have appeared in relation to events as they unfold. One of the key moments in the conflict was the referendum on self-determination, which was approved, prepared, and held on 1 October 2017, in the face of continuous opposition from the Spanish State. The tensions, uncertainties, and fears experienced by those in favour of the referendum were fuelled by rumours that in many cases were ultimately proven to be false. The present paper will analyse the rumours that emerged in relation to the referendum and the political atmosphere at that time. The study will analyse the rumours relating to aspects such as the logistics required to hold the referendum, the key figures in the process, the organizations that support it and the actions of the media, among others.
\end{abstract}

Keywords: Catalonia, independence, referendum, rumour, self-determination, Spain, WhatsApp

\section{INTRODUCTION}

For years now Catalonia has been in a situation of political conflict with the Spanish State in relation to the right to self-determination. The last time that Catalonia regained its parliament was after Franco's dictatorship, in the first 
years of the transition from the dictatorship to democracy, specifically in 1979, with the passing of a new Catalan statute of autonomy that in many respects was more restrictive than the one approved in 1932, during the second Spanish republic. ${ }^{1}$ Since 1979 , the Catalan people have constantly aspired to greater autonomy. In 2006, after years of difficult negotiations, in a referendum the Catalan people approved a new statute of autonomy, which had been agreed on with the Spanish government. However, in 2010 the constitutional court (which is highly politicized and chiefly made up of conservative judges) revoked some very significant articles of the statute, at which point many Catalans came to the conclusion that they would only achieve effective self-government by becoming independent from Spain. Since 2010, when the first massive demonstrations protesting against the actions of the constitutional court ${ }^{2}$ occurred, every 11 September ${ }^{3}$ there have been huge demonstrations for independence.

The Catalan Government responded to this social demand for independence by holding a non-binding consultation of the Catalan population on 9 November 2014. The results showed majority support for independence. This led the Catalan Government to convene elections to determine the majority position of the people living in Catalonia. The electoral programmes of the pro-independence parties clearly stated their political will to work to make Catalonia's independence possible. The elections were held on 27 September 2015 and the pro-independence parties achieved absolute majority. With this democratic endorsement, the Catalan Government requested the Spanish Government on repeated occasions to be able to make a referendum; however, in view of the continual refusal to address the issue, the pro-independence parties began the process in the Catalan parliament of planning and holding a referendum. In fact, during the first half of 2017, according to the barometer of the Centre d'Estudis d'Opinió (Opinion Studies Centre) of the Catalan Government, 73.3\% of people living in Catalonia were in favour of holding a referendum on selfdetermination, and $50.3 \%$ were in favour even if the Spanish government did not agree (Moldes 2017).

This situation of disagreement between the Catalan and Spanish governments provoked a growing conflict. One of the peaks of this conflict was the approval, preparation, and holding of the referendum on self-determination that took place on 1 October 2017. Despite the many attempts by the Catalan Government to arrive at an agreement with the Spanish Government for holding the referendum, this was not possible. Finally, the referendum was organized in the context of continued opposition from the Spanish Government. The tensions, uncertainties, and fears experienced by the people in favour of holding a referendum were fuelled by rumours that in many cases were revealed to be untrue. Tension began to increase from 7 September 2017, when the Catalan 
Government signed the order for the referendum for 1 October 2017. The Spanish Government reacted to the initiatives aimed at holding the referendum by sending around 6,000 police officers to Catalonia, modifying Spanish laws to limit the actions of the Catalan Government, increasing the Spanish intelligence service activities, intervening in the Department of Economy of the Catalan Government and trying to prevent all preparations of the Catalan Government (for example, the elaboration of an electoral roll).

In this context, the objective of this paper is to analyse the effect of rumours spread in the days before the referendum on self-determination, which is when the tensions reached one of the highest points in the conflict. If we apply Westerman's (1996) proposal, we can say it is an example of "the folklore of politics" insofar as it was a sample of folklore produced by a specific community as a result of a political conflict.

Specifically, we analyse the rumours discussed in a WhatsApp group formed by 23 people in favour of holding the referendum. The intention is to provide a sample from the period before the referendum of the themes that concerned the population and how they reacted to certain actions taken by those who were against it. Although the number of examples is limited, it can still give an idea of the atmosphere in Catalonia during those days and of how people transmitted their fears by reacting to the rumours that were generated in this period of emotional conflict. In this regard, the article studies a brief period in the history of Catalonia (the days leading up to the referendum on 1 October 2017) as it was experienced by a certain group of people (the participants in the WhatsApp group) with the limitations that this implies. ${ }^{4}$ However, it is precisely these limitations that allow us to observe in detail the reactions of a specific social group in the context of the more general political situation of conflict with the Spanish state and the international reverberations that this had. The analysis seeks to contextualize the presence of these rumours among this specific part of Catalan society and the context that led to them being generated.

\section{THE STUDY OF RUMOURS}

DiFonzo \& Bordia (2007: 273) define a rumour as "unverified and instrumentally relevant information statements in circulation that arise in contexts of ambiguity and that function primarily to help people make sense and manage threat". According to these authors, rumours have the following characteristics: (a) They are information statements. They are not about the views that people share because rumours aim to be informative; ${ }^{5}$ (b) They circulate within a certain group. They are not thoughts that are kept private; (c) They are not 
verified, which is not to say they are untrue, since a rumour can actually be true or false; ${ }^{6}$ (d) Finally, rumours are "instrumentally relevant". They answer questions that are important or meaningful to people. They can also be understood as revealing the "group sensemaking activity" because they serve to help people understand an ambiguous situation. Sunstein (2014: 4), for his part, defines rumours as "claims of fact - about people, groups, events, and institutions - that have not been shown to be true, but that move from one person to another, and hence have credibility not because direct evidence is available to support them, but because other people seem to believe them".

Although in this article we focus specifically on the study of rumours, we have nevertheless benefitted considerably from other studies that have analysed the phenomena of fake news and legends (such as Ellis 2018; Frank 2018; McNeill 2018; Mould 2018a, 2018b). The reason for this is that certain reflections by these authors regarding fake news and legends can also be applied to rumours, as will be seen subsequently.

The psychological aspect of the rumour is a key factor in understanding its appearance in conflictive situations. In their study on rumour psychology, Allport \& Postman (1988 [1947]: 23-24) explain how a rumour is started and continues to be spread in a homogeneous social environment, based on the active interests of the individuals involved in spreading it. The powerful influence exercised by these interests demands that the rumour serves as an element of rationalization. That is, it serves to explain, justify, and attribute meaning to the emotional interest that acts there. Sometimes, the link between interest and rumour is so intimate that the rumour is nothing more than the projection of a completely subjective emotional state.

As for the reception of rumours, Buckner (1965: 55-59) takes into account the knowledge the receiver has about the rumour's content, their previous experiences and the information they have about the person spreading the rumour. And, from here, three possible reactions are established: (a) A critical attitude (critical set). The individual can recognize incongruities in the rumour, detect their veracity and try to solve these incongruities; (b) A non-critical attitude (uncritical set). The person can speculate on the rumour, modify it, and distort its content; (c) A transmitting attitude (transmission set). This is characterized by the little interest that the rumour has for the individual.

It is also necessary to consider the importance of the group's characteristics in the process of spreading the rumour. According to Knapp (1944: 34-35), the factors that need to be considered are: (a) The group climate: the more information circulating among the group members, the higher the probability of spreading a rumour; (b) The homogeneity of the group: the greater the homogeneity of feelings and emotions within the group, the more easily the rumours will 
be spread (and this is inversely true for their rejection of the rumour); (c) The need for information: the greater the group's need for information, the better the atmosphere will be for creating rumours; (d) The character of the group: in static groups, characterized by their members' monotony, boredom or passivity, rumours are generators of enthusiasm. In this regard, Ellis (2018: 402) points out that these types of stories "circulate among groups of people who know each other well and share common standards of interest and plausibility". ${ }^{7}$

Regarding the credibility of the rumours, we can find parallels with the way rumours behave, in contrast to fake news, following the distinction proposed by Mould (2018b: 414):

Fake news describes a story intentionally and knowingly made up. Legend requires credibility and the possibility that the story could be true. Fake news created as false cannot be a legend because there is no doubt about its truth. Only when picked up and shared by others who see the story as credible, even if they doubt its accuracy, can it be considered legend.

In our case, as we will see subsequently, the credibility of a rumour is one of the factors that needs to be taken into account when analysing this corpus.

\section{RUMOURS IN A WHATSAPP GROUP}

WhatsApp groups, due to their communication features, allow people to interact and therefore contribute to effective spreading of rumours. As Astapova affirms (2017: 24): "The Internet in general becomes a significant scene and a meeting ground for questioning the existing system - as the real protests are suppressed and the access to offline public space is limited and regulated." A WhatsApp group provides a good opportunity to study the preoccupations and reactions of the participants because they express themselves freely in a private setting. It is this that makes this channel of communication ideal for the study of rumours during a political conflict.

Below we comment on some of the rumours that appeared in a WhatsApp group with the following characteristics: it is made up of 23 people, men and women between 25 and 67 years old, they communicate in the Catalan language, they have university degrees and are mainly in favour of Catalonia's independence. The initials before each message represent the name and surnames of each group member. They are presented in this manner to protect their privacy and to make it easier to present the information from this group. The authors of the present article are members of the group, which is how they have been 
able to access the messages. This is common in this type of folklore studies, as noted by McNeill (2018: 493): “As a folklorist, and especially as a legend scholar, I know that much of the information we pass along is not shared and received in the context of research, but rather in the context of informal interaction with other members of our many folk groups."

We have limited our role in this group to that of observers so as not to interfere with its dynamics and to better reflect the real interactions among the group members. In this regard, we are positioning ourselves in a manner that, according to Mould (2018a: 373), is appropriate for folklorists when they are studying phenomena similar to rumours, such as fake news. Thus, the role of the folklorist enables: "(1) recognition that truth and belief are constantly negotiated in the act of performance, (2) attention to emic genres, (3) attention to shifting contexts, and (4) focus on both how people share stories and why". Consequently, the authors of the present article have not participated in the WhatsApp group to either confirm or deny the rumours shared, because, as Frank states (2018: 385): "It isn't necessarily the job of the folklorist to defend or promote this material, but to do what we have always done, which is to try to account for the artistry of folklore and to understand how it expresses the ethos of the group that shares it".

The rumours analysed have been drawn from a selection of the conversations held by the group between 7 September and 1 October 2017, which is the time period between the signing of the order for the referendum until it was held. By selecting certain conversations, we are able to reduce the amount of material presented and to show the rumours that generated the largest response and reaction among the WhatsApp group members. Within this timeframe, the first rumour appeared on 12 September 2017 and, from that date onwards, the number of rumours continually increased as the referendum date approached. This period was especially prone to the emergence of rumours. As Allport \& Postman affirm (1988 [1947]: 27), the circulation of rumours reaches a frenetic point when the public is waiting for a long-awaited event.

The rumours are presented in chronological order. The brackets indicate the comments that describe the group members' actions that complement the information given.

\section{2/09/2017}

LK: Look what I've just been sent [photos of police vans].

MC: Yes, MS, state of siege. That's behind my house. I couldn't get in to see what the photos show. 
JZ: Is it the Civil Guard or National Police?

MC: It's the Civil Guard barracks, but you can see the vans are of the Spanish Police. Actually, they say these barracks aren't active... but... there's always movement.

JL: I would say that they're just there to do the weapons permits.

$M C:$ Yes, that.

MP: Om, om and om... Breathe... and keep going until the first of October. Post any "strange" movements in the networks. With a smile, the revolt and our anger contained! Until the 2nd of October.

$M P$ : [Shares a photo of the police].

MC: That's Reus.

MP: They're staying at the Hotel Gaudi. Maybe they came to decide if Gaudi [is] from Reus or Riudoms.

MC: Probably. Manoeuvres, you know.

One of the concerns of the days before the referendum was the deployment of Spanish security forces (National Police, Civil Guard, and the army) who had been brought to Catalonia, the first two with the excuse of helping the Catalan Police (the Mossos d'Esquadra) ${ }^{8}$ to preserve public order if necessary, and the third for the supposed need to perform military manoeuvres. Through the social networks and messages in WhatsApp groups like this one, people shared the images of Spanish army vehicles on Catalan roads and in different Catalan cities, presented as if they were recent photographs, when in fact they were taken in previous military manoeuvres. In this particular case images of a Civil Guard barracks in Reus, near to where two of the WhatsApp group members (MC and JL) live, are shared. MC confirms the location of the images (because of the proximity to their home), although they say that they cannot verify the authenticity of the photographs. The interventions by MP are very significant. Firstly, they ask for calmness and restraint, and encourage the other group members to keep a peaceful attitude towards this situation (with words that are often used in yoga sessions: "Om, om and om... Breathe...”) while encouraging sharing similar images through the social networks; they also use the expression "with a smile, the revolt" part of the chorus of the song "And with a smile, the revolt" by the singer-songwriter Lluís Llach composed in 1982, several years after the end of the Franco dictatorship. Secondly, after having shared another image of the police, they use humour to take away tension from the topic that is being discussed when they say that the security forces are staying at the Hotel Gaudí (correct information) to find out whether the modernist architect who gives his name to the hotel (Antoni Gaudí, 1852-1926) was actually born in Reus or Riudoms, a controversy still alive today among the inhabitants of 
these two places, and which is often the object of jokes between the defenders of the two different origins. The use of humour in these types of situations should be borne in mind because "[s]imilar to rumors, jokes provide a vent for frustration and an outlet for emotions" (Astapova 2017: 40). ${ }^{9}$

Finally, MC intervenes ironically and comments that it must be "manoeuvres", in clear reference to the justification given by the Spanish Government to the Catalan authorities to explain the presence of the army in some areas of Catalonia.

\section{7/09/2017}

JC: [Shares with the group two messages that have been sent: one about the Catalan Police and the other about the day of the referendum] The Catalan Police, who I have spoken to, hope that when they arrive, they'll find the polling places so full of people that they won't be able to get in or do anything to prevent people from voting. They told me that if that's what happens, they won't use force. If you want, you can share this. Go to vote very early. The important time is from 8 to 10. It is important that participation is high at the start because the no-voters feel questioned. It would be good for people that aren't volunteers to stay "guarding" the polling places. There need to be people in case the police or some fascists come. Keep watch all day. DO NOT print the ballots. They would be invalid. Don't be scared. Calmness and a cool head. Share it.

These two messages were sent to me. I don't know if they're true, but I'm sharing them anyway.

$M S$ : [Repeats the two previous messages, in the reverse order, which have been sent by a reliable source, XG, dated 16/09; the messages are accompanied by the following information]

I have just asked a friend of mine who is high up in the Catalan Police and he says that it is totally true.

The advice is that we share it as much as we can.

For the referendum to be a success it is very important to spread this information as much as possible.

The proliferation of messages in WhatsApp groups, especially the ones with many participants, causes the same messages to be shared repeatedly, even almost immediately. This is an example. JC shares two messages with practical instructions for the day of the referendum, supposedly coming from the Catalan Police. Immediately afterwards, MS shares the same information (received the 
previous day) reversing the order of the messages, which shows the changes caused by the circulation of these messages by different means. Regarding the attitude of the sender, while JC shows doubts about the information, MS shares it without going into personal evaluations. On the truth of the shared information, the second source explains that a police agent has verified the information, which gives more credence to the rumour.

\section{0/09/2017}

$M S:$ [Shares the following message with the group] ATTENTION

The demonstration in support of our institutions and in DEFENSE OF DEMOCRACY is RIGHT NOW in Rambla Catalunya with Gran Via (Barcelona). Do NOT listen to rumours that say it is at Plaça Sant Jaume. Only follow directions from official sources. SHARE IT!

$M C$ : [Sends an image of a police car]

$O T$ : [Sends three images of police cars on the freeway]

I don't know if they are reliable.

$M C:$ Noooooo.

MA: Don't spread panic!

$M C$ : [Sends a video of police cars on an avenue of a city]

PN: MC, these images are from the SPANISH BIKE TOUR! Let's not mix things.

MC: FF sent them to me. Because I'll believe them... And the photos are of manoeuvres from who knows when. I didn't see the BIKE TOUR, so I didn't recognize them.

$P N$ : Me neither.

FM: You can't believe everything you're sent... Those ones of the cops on the highway are also from the Bike Tour... Be careful!!

PN: They told me here, at the TNC. ${ }^{10}$

MC: Thinking a bit, it doesn't fit at all with what's happened today. Sorry everyone. Well, well. It wasn't just me that did it. Don't tell only me off. I'm sorry.

PN: We're not telling you off, $M C$.

The Spanish judicial and police strategy to prevent the referendum from being held was determined in a new action on 20 September. The actions of the Civil Guard, with the arrest of senior officials of the Catalan Government and the entrance into several ministries to look for clues about the preparations for 
the referendum, motivated an immediate response from the civil population. Thousands of people demonstrated peacefully in different parts of the city of Barcelona, including in front of the Ministry of Economy, to denounce acts of repression and demand that the referendum be held. It is in this context where we must place the message that MS shares with the group. This message is a call to join the demonstration in Barcelona, specifically at the junction of Rambla Catalunya with Gran Via, thus denying rumours that the protesters should go to another part of the city (Plaça de Sant Jaume). The accelerated succession of events on these days, together with the repressive actions of the Spanish State and immediate replication of the civil society, led to episodes like this, in which there was a certain degree of confusion about the place where people needed to go. The emergence of rumours (and contra-rumours) proliferated confirming and denying the actions to be carried out.

Next the group began talking about a topic that had already appeared previously, the presence of the Spanish Police in Catalonia. On this occasion, MC shares a video showing police cars. Immediately afterwards, PN denies that they are current images because they come from a sporting event, the Bike Tour in Spain. MC justifies sharing the video because it comes from a reliable source (FF). This shows that it is important that the sender is a trusted person, since this could determine, in some cases, the re-sharing of the message. This is a basic factor when rumours are shared. As McNeill (2018: 496-497) points out with regard to the way we share information that comes from social media, the credibility of the source and the trust we place in it determine how we share the information received:

We may seek out additional depth on some of the information that comes to us via social media, but we rarely look into all of it. And why would we? We have a trusted source (who surely read the whole article start to finish, unlike ourselves) and a plausible and intriguing headline, so we pass it on, we repost it. This is, of course, a common and familiar process of legendry that just happens to play out in the transmission of fake news as well. We get a short blip of information from a trusted person, and then we pass it on with a similar lack of depth. Not as a 'story', but as conversation, as information, as exposition.

FM intervenes to confirm once again that the shared images are from the sporting event and adds that one needs to be careful before spreading the information one receives. In response to this reaction, $\mathrm{MC}$ apologizes for having spread a rumour. PN closes the conversation on the subject with an understanding attitude towards MC. 


\section{1/9/2017}

$F M$ : [Shares the following message with the group]

Friends and Catalans. People who love Catalonia and therefore want it free and independent (like me).

These days there are many jokes, "memes", denouncing and complaining about the attitude of the Spanish Government to our determination to hold the referendum on 1 October. Well, as far as I'm concerned, I'm going to stop sharing unproductive information.

[...]

The great problem that Rajoy ${ }^{11}$ (and the entire Spanish Government) has is that they KNOW that if we vote and we are many people, this is unstoppable because they have been warned from the outside.

Arriving to this conclusion they have no choice but to create FEAR so that people will not vote. It is their only salvation, and so they are moving policemen, civil guards, military, machine guns... and, don't get scared, but they will move tanks, and they will do everything they can to frighten us so that on 1 October we stay at home.

They cannot stop us from voting with violence (because, in order to use violence, there must be someone in front of them who responds to the violence. And we will not do this). The only way they can win is by dissuading us so that we make the project fail by not going to vote. That is why I want to explain what I will do on 1 October:

I will get up very early, very early (as Guardiola said), ${ }^{12}$ I'll make some sandwiches, I'll get a bottle of water and a backpack, and I will go to the polling place calmly and serenely. Willing to vote or spend the day. As if it were another 11 September.

If I can vote, fantastic. If not, I propose staying peacefully in our respective polling places so there are more and more people in a festive and peaceful atmosphere (as we have done in recent years for our national day) until there are thousands of people for the photos that will travel around the world. We must win this fight for freedom and our rights. And the best way is with wisdom and serenity. With calmness and good work.

Over the next few days the pressure of the government will increase, but we must be able to reach the 1st of October and go to vote, EVERYONE. Whatever happens, on the 1st of October EVERYONE SHOULD GO. Then we'll have it in the bag. If you agree, I would be grateful if you shared this written text to ensure maximum attendance at the polls. I personally will share it every day until the 1st of October. The moment of truth is here and we can't get distracted.

There are only 11 days left. FOR CATALONIA AND CATALANS. 
MC: Friends, I received this. I don't know if it is police or something to discourage the good people. I hesitated to pass it on because I don't want to collaborate in discouragement. Now, I think it is important to be informed. This has to stir us to fight even more.

[Voice message in Spanish]: Yes, completely true. Eh... The thing about the ships is true. There are two ships in the port of Barcelona and one in the port of Tarragona. I'm telling you. Giant Cruise Ships. And the entire $U I P^{13}$ and part of the UPR ${ }^{14}$ are staying on them and they'll probably put the Civil Guard on them too. Eh... Yes, there are $G R S^{15}$ and $G A R^{16}$ who are staying there. OK? I'm in Calella. That always ... And there are 200 thousand GRS. But it's true that the ones that come now don't have anywhere to stay. And apart from having nowhere to stay they go to the villages and the villages don't want problems. Look what's happening in Reus. So the Commissariat General of Citizen Security (this comes from the minister, so it also affects the Civil Guard) has decided to grab three huge ships and they can all stay on them. They'll set up security in the port and work regularly. I still don't know if they'll move me to the ship or if I'll stay at the hotel, but, yes, yes, almost all the rumours that you are hearing are true. And there are enough police here to raze Beirut. They need to let us act because, for now, today, the demonstrations are quiet, quiet, and they go past and insult you and they go past and say whatever they want, until we get really pissed off, of course, and we hit who we need to hit.

MA: That's going around Twitter, but nobody knows where it came from. There's no reliable source. Maybe it's been set up or not. But when they don't say who said it, its suspicious.

JC: I hadn't heard it before. They could have spread it to scare people so they don't go to vote. But we know that they are capable of reacting like that... we'll see.

FM: Is this just one more crazy thing? I mean the recording.

MC: I prefer to follow the one about the person who explains what they'll do on 1 October. It seems much more believable.

This message brings together two contrasting rumours with clearly opposing intentions. First, FM shares a text that evaluates the current situation, comparing the referendum on 1 October 2017 with the non-binding consultation organized by the Catalan Government and held on 9 November 2014. This rumour shows confidence that the referendum will be held "because they have been warned from the outside", in clear reference to another rumour circulating at that time, according to which the highest international authorities would 
accept the result of the referendum. These recurring issues were supported by, as happens with fake news, the existence of generic news about the statements of some leaders of other countries in relation to the referendum. In this message another recurring theme also appears: how to act on 1 October. In this case, the message does not only give encouragement to vote, but also practical and attitudinal tips (bring a sandwich and a bottle of water when you go to vote) as if it were a day for celebration and protest, like the national day of Catalonia (11th of September). It has the clear intention of encouraging supporters of Catalan independence not only to go to vote but to also go well prepared to stay the day at the polling places to be able to vote.

The second part is a transcript of an audio recording. Of uncertain origin, this message is in Spanish and is presumably a police officer who confirms the arrival of the state security forces in Catalonia and explains the orders they have been given. It is, in this case, a message released by opponents of the referendum and clearly intends to demoralize and frighten the possible voters so that they will not go out to vote on 1 October. MA confirms that the audio message is also circulating in other social networks and expresses doubts about its authenticity, since its origin is not given. MC's reaction, who shared the audio message, is positive in the sense that $\mathrm{MC}$ says that "it is important to be informed", adopt a critical position and not be intimidated. JC thinks that the intention of this message could be, in effect, to discourage people from voting. MC intervenes again to say that they prefer to follow the indications of the previous message that FM shared, which encourages voting, not only because of what it says, but also because the message seems much more credible.

\section{2/09/2017}

$L K$ : [Shares the following message with the group]

From a very reliable source of the Catalan Government. The prediction is that during the weekend they will lower the pressure level but the strong blow will come on Monday or Tuesday: the arrest of councillors and the president of the government and intervention in all the Catalan media: TV3 and Catalunya Ràdio. We all need to be ready to go out onto the streets and completely stop the country.

The Spanish Government's plan to stop the referendum is circulating in Facebook. First, disable the entire Catalan Government. Second, make the delegate of the Spanish Government Enric Millo acting president. Third, dissolve the parliament and convene autonomous elections in November or 
December. WE CAN'T LET THIS HAPPEN, BECAUSE IT IS A COUP! Share it with your contacts. It is IMPORTANT.

MA: Don't share that! Nobody has the power to dissolve the Parliament and less to nominate Millo. Only the elected president can call elections. ENOUGH, PLEASE!!

Don't spread catastrophic rumours - for your own health and for everyone's wellbeing. Be positive and brave.

MC: You're right, MA. Let's keep going! We all know where we have to be and what we need to do.

MS: Would you stop spreading panic? It's like we've been infiltrated. Please, remember the recommendation not to spread rumours.

$S V$ : Let's lower the tension...

$M S$ : [Sends the group the following message sent to them by a friend] Hello, trolls are circulating to discourage people. If you receive a message that is not well endorsed and identified, it is advisable not to spread it.

MC: OK! The only thing the State can do is demobilize the vote through fear. We can't fall into the trap.

$F M$ : [Shares the following message with the group]

IMPORTANT WARNING

We only share messages that come DIRECTLY FROM OFFICIAL SOURCES such as this channel (or those of the ANC, ${ }^{17}$ parties, the government).

The rest are FALSE rumours that THE STATE GENERATES to deceive and frighten. Let's not be fooled, let's not spread them!

To avoid confusion, I'm sending the channel's link to everyone so they can join it!

http: / / cridademocracia.cat/ws /WS

LET'S STAY CONNECTED!

SHARE IT!

MP: One of the historical forms of repression is to spread false rumours without any evidence in a language that spreads a sensation of anxiety and fear. Try to share only information that you have experienced, that you have contrasted or that is accompanied by documentation that guarantees it.

SV: Good recommendation, $M P$.

JC: Spanish Unionists threaten with a video of a train full of tanks and it turns out that it is a lie (www.vilaweb.cat).

I totally agree with all that about rumours. This is a clear example. 
MC: Someone sent me a video of a train full of tanks a few days ago. I am sad that such a terrible lie should be spread around. I didn't share $i t$, of course.

LK: The same thing happened to me.

JC: Yes, me too.

This message shows the uncertainty about whether the referendum will be held due to the actions of the Spanish Government. On this occasion, unlike the previous occasions, the subject of the security forces intervening to prevent the referendum is not talked about but rather the direct action of the Spanish Government is discussed. According to this rumour, shared by LK, to stop the referendum, the Spanish Government would dissolve the Parliament, proclaim Enric Millo (delegate of the Spanish Government in Catalonia) the president of the Catalan Government and intervene in the public media (Televisió de Catalunya TV3 and Catalunya Ràdio). The message causes some group members to instantly react and highlight the unbelievable nature of the rumour, since only the president of Catalonia can call elections and a president of the Catalan Government cannot be appointed on an interim basis. But even more interesting is the rejection of the rumour by MA and, especially, MS. MA strongly rejects spreading "catastrophic" rumours and MS asks all the group members to remember the recommendations of "not spreading rumours". MS, with the intention of insisting on the convenience of not spreading rumours, shares a message received from a friend who recommends not sharing the messages that clearly have catastrophic and alarmist intentions.

The second message, shared by FM, requests people to only spread the information that comes from reliable sources to avoid the proliferation of rumours that create alarm. In this sense, MP again gives their opinion on the subject and states the fact that precisely this is a strategy commonly used in these types of situations in order to spread "a sensation of anxiety and fear".

\section{3/09/2017}

FM: [Shares the news "The State takes control of the Catalan Police before 1-O" published in El Periódico on the same day $\left.{ }^{18}\right]$

Now we don't have our police force.

$M C$ : [Shares the following text signed by the Call for Democracy group] Attention

In the face of the new and constant ATTACKS FROM THE STATE, our response will always be CALM, ORGANIZED AND PACIFIC. 
That is why we reinforce the CALL to FILL this Sunday (11am) the squares of Catalonia to participate in the MARATHON FOR DEMOCRACY and we deny that there is any other demonstration organized.

* WE DO NOT BELIEVE RUMOURS, THEY ARE PART OF THE STATE'S DIRTY WAR. SHARE ONLY OFFICIAL SOURCES (Crida, ${ }^{19}$ $A N C,{ }^{20}$ Òmnium, ${ }^{21}$ parties $\left.^{22}\right)$.

We respond to the State with an UNSTOPPABLE WAVE OF DEMOCRACY!

SHARE IT!

-Call for Democracy-

FM shares the news item "The State takes control of the Catalan Police before 1-O”, according to which the Catalan Police became coordinated, along with the Civil Guard and the National Police, by the Civil Guard Colonel Diego Pérez de los Cobos to prevent the referendum from being held. FM's comment that accompanies the news item is significant because, with this measure (which did not become effective), the Catalan Government's security forces would be directed by the Spanish Government. This news reflects one of the concerns of referendum supporters: that the Catalan security forces would have to act against them because they would be ordered to reinforce the opposition already established by the Spanish Government with the National Police, the Civil Guard, and even the army.

In opposition to this news item, MC shares a message signed by the "Call for Democracy" group that encouraged participation in the so-called "Marathon for Democracy"23 while reinforcing the idea that only the instructions received from official sources should be followed to avoid the "dirty war" being played by Spain in its attempt to prevent the referendum from being held.

\section{4/09/2017}

MS: [Shares the link to the news item "A victory, yesterday, we have to understand well" published the day before (09/28/2018) in the electronic newspaper Vilaweb ${ }^{24}$ ]

Very important. Read it. Don't spread rumours, we'll lose democracy that way.

In relation to the spread of rumours, MS shares the editorial by the journalist Vicent Partal, "A victory, yesterday, we have to understand well". It is about one of the most repeated slogans of the Catalan institutions and, especially, 
the pro-independence entities (Assemblea Nacional Catalana and Òmnium Cultural) and civil society. Whatever the Spanish Government does to stop the referendum, the reaction of the referendum supporters must be peaceful. On the one hand, to show the legitimacy of the demand (exercise the right to vote to determine the position of Catalan society on the right to self-determination) and, on the other, to not give the Spanish Government reasons for exercising violent repression.

\section{9/09/2017}

MC: Question: If you go there with the ballot paper, what envelope do you have to put it in? I suppose there is an official size and shape. And if there aren't any at the polling place? I'm worried. I'm sure you need an envelope to place your vote. Does anyone know?

OT: Do not bring ballots printed at home. The Assembly ${ }^{25}$ assures us that there will be enough at the polling places!

MP: Ballots and envelopes at the polling places. For now, that's how it is. MA: On the Assembly's Telegram they give a link. It says that if you bring them from home, they won't be valid.

MC: Today they just sent this:

Every day there are rumours and messages sent in the name of the ANC. Don't believe any that do not come from the ANC's official channels: our Twitter, Facebook, Instagram, or this channel of Telegram.

They ask everybody to go on 1 October to vote with ballot papers and show them, so that it is clear that we are going to vote. If we have to cue, it's with the ballot papers in our hands!

They'll be valid!

You can download it from this link: http: / / bit.ly/papereta.

However, there will be ballots and envelopes in the polling places. Don't worry.

Let's go! And today we'll fill Montjü̈c!

Catalan National Assembly

MC: They deny the following message as a false message attributed to them. [Logo of the Catalan National Assembly]

A few days ago, the idea of carrying voting ballots from home in case there are none at the polling place has spread among the population, DO NOT DO THIS. If the ballot paper is not exactly the same as the official ballot paper, it will be counted as an INVALID vote. Please be assured 
that there will be ballots, envelopes, ballot boxes and everything that is necessary at the polling places.

Spread this notice to all your family and friends.

JZ: You are collapsing me with so much information. Right now I don't know what I have to do. Take a ballot paper? Don't take one?

MA: There'll be ballot papers at the polling places. If you can't get in, if they have been stolen and someone gives you one that is homologated, it will also be valid. There is a solution for every problem.

This last message, shared in the group two days before the referendum was held contains diverse (and contradictory) information about one of the issues that worried people most in the days before the referendum: having ballot papers and ballot boxes for voting. This concern was shared by the referendum supporters and those against it: the former to ensure that they could exercise their right to vote in all the polling places, and the latter (including the Spanish Government) for the opposite reason, that is, to prevent the referendum from being held. In fact, the Spanish Government put considerable effort into searching for the ballot papers and ballot boxes precisely with the intention of destroying them and thus making it impossible to vote.

MC expresses their doubts in relation to ballot papers (and envelopes) and how to act if there are not any at the polling places. OT and MP respond that it is not necessary to bring the ballot papers from home because there will be some at each polling place. MC expresses their doubt by sharing two messages, both allegedly sent by the Assemblea Nacional Catalana (Catalan National Assembly). The first message provides a link from which you can download the ballot paper, although it is stated that there will be papers at the polling places. The second message, supposedly false and denied (apparently) by the same entity, requests people not to bring ballot papers printed at home because they will not be valid, which would undermine the favourable option for independence in the vote count. At this point JZ intervenes and says that, in the wake of all this information on ballot papers, they do not know what to do. MA replies that there will be ballot papers at the polling places and that it will not be necessary to bring them printed from home. This is a good example of the consequences of spreading contradictory rumours within the same group and in a short space of time. MC's intention is to clarify the doubts generated by the messages received about the ballot papers, but by sharing the information they have received, the opposite effect is achieved, which is seen in JZ's reaction. Finally, MA says that there will be ballot papers in the polling places, but if there are none, those brought from home will be valid. With MA's closing statement, "There is a solution for every problem", we see one of the key 
characteristics of the referendum, the capacity of the Catalan Government and the people who favoured the referendum to provide solutions for making their long-wished-for objective possible: to be able to vote. ${ }^{26}$

As seen in the transcribed messages commented on here, in the analysed WhatsApp group we can observe a great deal of activity regarding the spread of rumours about the referendum for self-determination on 1 October. Of the 23 people who make up the group, 12 participated actively, either by spreading or denying rumours, thus characterizing the group climate (Knapp 1944: 34). In this sense, we can see that participation is more active and energetic when it comes to refuting some of the shared rumours, which can be seen, for example, on 20, 22, and 29 September 2017. As Knapp (1944: 35) has pointed out, the need for information at certain times (a clear example is 29 September with the doubts about the ballot papers) intensifies the circulation of rumours. This spreading of rumours is favoured by the homogeneous nature of the group, made up mostly of people in favour of independence and receptive to receiving any kind of information that, on the one hand, ensures that the referendum can be conducted, and on the other hand, warns of the possible actions carried out by the Spanish Government to stop it from being held. It is in this second case that the rumours generate a more enthusiastic reaction from the most active members of the group, directed mainly at denying the received information and counteracting it with advice that helps to correctly manage personal emotions.

Some group members have a critical attitude (Buckner 1965: 55-57) as they are active in giving evidence of the incongruities in the rumours that generate most concern and alarm, and at the same time ask the rest of the group members to take on a critical attitude faced with the avalanche of information received in those days.

Some of the group members, like JC, do this by accompanying the shared information with comments that show their critical attitude (for example, in messages on 17 and 22 September 2017). MS is the clearest example of this critical attitude, both in the comments about the information sent by other members, and also in their active role in sharing information that can help control rumours, as is clearly seen in the message on 24 September. In terms of the interest generated by the rumours, it can be seen that FM is the most active member of the group in sharing messages, which are usually not accompanied by any kind of personal assessment. 


\section{CONCLUSIONS}

The rumours studied in this work reveal the issues that were perceived as most relevant to the success or failure of the referendum for self-determination. The referendum was organized and convened by the Catalan Government and not agreed on with the Spanish Government, and in fact with the latter's constant opposition. This led to many uncertainties among the population about whether the referendum could finally be held or not. In the case of people in favour of holding the referendum, studying the communications in the analysed WhatsApp group provides some data on what the most visible concerns of the participants were. Specifically, between 12 and 29 September, these people provided news, rumours, and comments in which it can be seen how, as the date of the referendum approached, the need for reliable information grew along with the desire to be able to vote. Among the topics most discussed in the group are those of fear about police intervention, the concern about the ballot papers and ballot boxes on the day of the referendum, the will to always act peacefully, the confidence in the information provided by the Catalan Government and the pro-independence entities, and the confidence in the selfless help and collaboration among people to achieve a common goal.

The studied WhatsApp group shared their doubts and fears, but they also showed their will to fight the rumours that were harmful as well as share resources for managing emotions. This desire to control the effect of rumours, which is observed in this WhatsApp group and which was also evident in other groups, was very important in the physical and, above all, mental preparation of the people who favoured the referendum. It was, in fact, one of the keys that made it possible to face the day of 1 October with strength and ensure its success. Some media helped identify the rumours that could have had a toxic effect on the population in favour of the referendum and alerted the public to their falseness in editorial comments or news. These were shared in social networks and messaging services like WhatsApp, which contributed to spreading these alerts and thus limited the negative impact of the rumours.

\section{ACKNOWLEDGEMENTS}

This study is part of the research by the Grup de Recerca Identitats en la Literatura Catalana (GRILC), established by the Catalan Government (2017 SGR 599) and was conducted as part of a project on Catalan folk literature, which received funding from the Spanish Government's Ministry of Science, Innovation and Universities, ref. PGC2018-093993-B-I00 (MCIU/AEI/FEDER, UE). 


\section{NOTES}

1 The Parliament of Catalonia has its origins in the Catalan Courts established in 1283.

2 The demonstration took place in Barcelona on 10 July 2010 under the slogan "We are a nation. We decide".

3 This is the national day of Catalonia that is commemorated annually, remembering the last defence of the city of Barcelona on 11 September 1714 in the War of the Spanish Succession. With the fall of the city, the institutions, constitutions and civil liberties of Catalonia were also abolished.

4 For a good introduction to "election folklore", see the article by Astapova (2017).

5 For Allport \& Postman (1988 [1947]: 167) the social problem of the rumour originates precisely because of the unique fact that the listener receives it as the expression of a fact and not based on the intentions of the person telling it.

6 Neubauer (2013 [2009]: 16-17) expresses himself similarly, in that the falsity or certainty of a rumour is not as important as the fact that it is current and does not have an identifiable emitter, since what everyone says is not a rumour yet, but what is said that everyone says, is a rumour. Nobody knows who is talking through a rumour.

7 Ellis bases this assertion on the contributions of Dégh \& Vázsonyi (1973).

8 The Mossos d'Esquadra are the police of the Catalan Government, created at the beginning of the 18th century. Reformed in 1983, they have functions including public safety, administrative police, judicial police, intervention, and police of proximity, which are competences of the Catalan Government.

9 Astapova bases this assertion on the contributions of Banc \& Dundes (1986: 10) and Dundes (1971: 51).

10 Teatre Nacional de Catalunya (National Theatre of Catalonia).

${ }^{11}$ Mariano Rajoy, prime minister of the Spanish Government (2011-2018).

12 The football trainer (and ex-player) Pep Guardiola, who has shown himself to be in favour of Catalan independence on several occasions, in the speech he gave when he received the gold medal from the Parliament of Catalonia (8 September 2011) said: "If we get up very early, very early, and there are no complaints, there are no excuses, and we get to work, we are an unstoppable country".

${ }^{13}$ Unidades de Intervención Policial (Police Intervention Units).

${ }^{14}$ Unidad de Prevención y Reacción (Unit of Prevention and Reaction).

${ }^{15}$ Grupos de Reserva y Seguridad (Reserve and Security Groups).

${ }^{16}$ Grupo de Acción Rápida (Rapid Action Group).

${ }^{17}$ Assemblea Nacional Catalana (Catalan National Assembly) is a civil society organization strictly independent of political parties and the administration, founded in 2012. It is defined as of the people, united, inclusive, and democratic, and aims to achieve the independence of Catalonia through the constitution of a state of law that is democratic and social (see https://assemblea.cat/, last accessed on 7 September 2021).

${ }_{18}$ Available at https://www.elperiodico.com/es/politica/20170923/el-estado-toma-elcontrol-de-los-mossos-ante-el-1-o-6305892, last accessed on 7 September 2021. The news was updated on 29 September 2017 and the headline changed to "The Government refuses to submit the Catalan Police to the control of the State". 
${ }^{19}$ Crida per la Democràcia (Call for Democracy).

${ }^{20}$ Assemblea Nacional Catalana (Catalan National Assembly).

${ }^{21}$ Òmnium Cultural is a non-profit organization founded in 1961, which works for the promotion of the Catalan language and culture, education, social cohesion, and the defence of the national rights of Catalonia (see https://www.omnium.cat/, last accessed on 7 September 2021).

${ }^{22}$ Pro-independence parties.

${ }^{23}$ The "Crida per la Democràcia" (Call for Democracy) was a campaign promoted by Òmnium Cultural with the aim of defending the referendum on independence. The campaign was embodied, among other actions, in the "Marathon of Democracy" that took shape in over 300 acts in front of town halls or hub centres of different cities and towns of Catalonia.

${ }^{24}$ Available at https://www.vilaweb.cat/noticies/una-victoria-ahir-que-hem-dentendrebe/, last accessed on 7 September 2021.

${ }^{25}$ Assemblea Nacional Catalana (Catalan National Assembly).

${ }^{26}$ This creative ability to deal with difficulties was evidenced on the day of the referendum with "the single census of voters", which allowed people to vote in any of the polling places that existed. Thus, many people who saw the police taking the ballot boxes from their polling place could go to another one to vote and therefore did not lose the possibility to vote.

\section{REFERENCES}

Allport, Gordon W. \& Postman, Leo J. 1988 [1947]. Psicología del rumor. Buenos Aires: Editorial Psique.

Astapova, Anastasiya 2017. Rumor, Humor, and Other Forms of Election Folklore in Non-Democratic Societies: The Case of Belarus. Folklore: Electronic Journal of Folklore, No. 69, pp. 15-48. https://doi.org/10.7592/FEJF2017.69.astapova.

Banc, C. \& Dundes, Alan 1986. First Prize: Fifteen Years! An Annotated Collection of Romanian Political Jokes. Rutherford, N.J.: Fairleigh Dickinson University Press.

Buckner, H. Taylor 1965. A Theory of Rumor Transmission. Public Opinion Quarterly, Vol. 29, No. 1, pp. 54-70. http://dx.doi.org/10.1086/267297.

Dégh, Linda \& Vázsonyi, Andrew 1973. The Dialectics of the Legend. Folklore Preprint Series, Vol. 1, No. 6. Bloomington: Folklore Publications Group.

DiFonzo, Nicholas \& Bordia, Prashant 2007. Rumors Influence: Toward a Dynamic Social Impact Theory of Rumor. In: A. R. Pratkanis (ed.) The Science of Social Influence: Advances and Future Progress. New York \& Hove: Psychology Press, pp. 271-295.

Dundes, Alan 1971. Laughter behind the Iron Curtain: A Sample of Rumanian Political Jokes. The Ukrainian Quarterly, Vol. 27, pp. 50-59.

Ellis, Bill 2018. "Fake News" in the Contemporary Legend Dynamic. History. The Journal of American Folklore, Vol. 131, No. 522, pp. 398-404. https://doi.org/10.5406/ jamerfolk.131.522.0398. 
Frank, Russell 2018. Fake News vs. "Foke" News: A Brief, Personal, Recent History. The Journal of American Folklore, Vol. 131, No. 522, pp. 379-387. https://doi. org/10.5406/jamerfolk.131.522.0379.

Knapp, Robert H. 1944. A Psychology of Rumor. The Public Opinion Quarterly, Vol. 8, No. 1, pp. 22-37. http://dx.doi.org/10.1086/265665.

McNeill, Lynne S. 2018. "My friend posted it and that's good enough for me!": Source Perception in Online Information Sharing. The Journal of American Folklore, Vol. 131, No. 522, pp. 493-499. https://doi.org/10.5406/jamerfolk.131.522.0493.

Moldes, Aleix 2017. Gairebé el 75\% dels catalans participarien en un referèndum unilateral, segons el CEO. [Almost 75\% of Catalans Would Participate in a Unilateral Referendum, according to the CEO.] Ara.cat, 30 March. Available at https://www.ara. cat/politica/catalans-partidari-referendum-votaria-independencia_0_1768623247. html, last accessed on 7 September 2021.

Mould, Tom 2018a. Introduction to the Special Issue on Fake News: Definitions and Approaches. The Journal of American Folklore, Vol. 131, No. 522, pp. 371-378. https://doi.org/10.5406/jamerfolk.131.522.0371.

Mould, Tom 2018b. A Doubt-Centered Approach to Contemporary Legend and Fake News. The Journal of American Folklore, Vol. 131, No. 522, pp. 413-420. https:// doi.org/10.5406/jamerfolk.131.522.0413.

Neubauer, Hans-Joachim 2013 [2009]. Fama. Una historia del rumor. Madrid: Siruela.

Sunstein, Cass R. 2014. On Rumours: How Falsehoods Spread, Why We Believe Them, and What Can Be Done. Princeton \& Oxford: Princeton University Press. https:// doi.org/10.2307/j.ctv6zddck.

Westerman, William 1996. Politics and Folklore. In: Jan Harold Brunvand (ed.) American Folklore: An Encyclopedia. New York \& London: Garland Publishing, pp. 570-574.

Emili Samper is Research Fellow (PhD) at the Catalan Studies Department at Rovira i Virgili University, Tarragona, Spain. His main research fields are folk literature from its origins until now, Catalan literature, and academic studies on comics. He has published articles on folklore history, contemporary legends, and comics, and has co-edited studies with Carme Oriol (A History of Catalan Folk Literature, 2019) and Magí Sunyer (The Myths of the Republic, 2016). He is also member of the editorial board of the journal Studies in Oral Folk Literature.

emili.samper@urv.cat

Carme Oriol is Full University Professor of Catalan Philology and Folk Literature and director of the Arxiu de Folklore at the Rovira i Virgili University, Tarragona, Spain. She has conducted fieldwork in Andorra and Catalonia. Her research interests include folk narrative and the history of folklore. She is 
co-author of the books Index of Catalan Folktales (Oriol and Pujol, 2008) and A History of Catalan Folk Literature (Oriol and Samper, eds., 2019) and director of the journal Studies in Oral Folk Literature.

carme.oriol@urv.cat 